\title{
Antifungal amphiphilic aminoglycoside K20: bioactivities and mechanism of action
}

\author{
Sanjib K. Shrestha ${ }^{1,2}$, Cheng-Wei T. Chang ${ }^{2,3}$, Nicole Meissner $^{4}$, John Oblad $^{3}$, Jaya P. Shrestha ${ }^{3}$, \\ Kevin N. Sorensen ${ }^{5}$, Michelle M. Grilley ${ }^{1}$ and Jon Y. Takemoto ${ }^{1,2 *}$ \\ ${ }^{1}$ Department of Biology, Utah State University, Logan, UT, USA \\ 2 Synthetic Bioproducts Center, Utah State University, North Logan, UT, USA \\ ${ }^{3}$ Department of Chemistry and Biochemistry, Utah State University, Logan, UT, USA \\ ${ }^{4}$ Department of Immunology and Infectious Diseases, Montana State University, Bozeman, MT, USA \\ ${ }^{5}$ Department of Biology, Snow College, Ephraim, UT, USA
}

Edited by:

Ana Traven, Monash Univerisity,

Australia

Reviewed by:

Julianne Teresa Djordjevic

University of Sydney at Westmead

Hospital, Australia

Karin Thevissen, Catholic University

of Leuven, Belgium

Marilyn Anderson, La Trobe

University, Australia

*Correspondence:

Jon Y. Takemoto, Department of

Biology, Utah State University, 5305

Old Main Hill, Logan, UT 84322,

USA

e-mail: jon.takemoto@usu.edu
$\mathrm{K} 20$ is a novel amphiphilic antifungal aminoglycoside that is synthetically derived from the antibiotic kanamycin A. Reported here are investigations of K20's antimicrobial activities, cytotoxicity, and fungicidal mechanism of action. In vitro growth inhibitory activities against a variety of human and plant pathogenic yeasts, filamentous fungi, and bacteria were determined using microbroth dilution assays and time-kill curve analyses, and hemolytic and animal cell cytotoxic activities were determined. Effects on Cryptococcus neoformans H-99 infectivity were determined with a preventive murine lung infection model. The antifungal mechanism of action was studied using intact fungal cells, yeast lipid mutants, and small unilamellar lipid vesicles. K20 exhibited broad-spectrum in vitro antifungal activities but not antibacterial activities. Pulmonary, single dose-administration of K20 reduced $C$. neoformans lung infection rates 4 -fold compared to controls. Hemolysis and half-maximal cytotoxicities of mammalian cells occurred at concentrations that were 10 to 32-fold higher than fungicidal MICs. With fluorescein isothiocyanate (FITC), 20-25 mg/L K20 caused staining of $>95 \%$ of $C$. neoformans and Fusarium graminearum cells and at $31.3 \mathrm{mg} / \mathrm{L}$ caused rapid leakage $(30-80 \%$ in $15 \mathrm{~min})$ of calcein from preloaded small unilamellar lipid vesicles. K20 appears to be a broad-spectrum fungicide, capable of reducing the infectivity of $C$. neoformans, and exhibits low hemolytic activity and mammalian cell toxicity. It perturbs the plasma membrane by mechanisms that are lipid modulated. K20 is a novel amphiphilic aminoglycoside amenable to scalable production and a potential lead antifungal for therapeutic and crop protection applications.

Keywords: antifungal, amphiphilic aminoglycoside, K20, Cryptococcus neoformans, kanamycin

\section{INTRODUCTION}

Fungal diseases are major threats to human health and food security (Strange and Scott, 2005; Fisher et al., 2012). Invasive human fungal infections such as cryptococcal meningitis caused by Cryptococcus neoformans have increased due to the rising number of immunocompromised individuals (Park et al., 2009; Shirley and Baddley, 2009). Fungal crop diseases such as wheat head blight or scab (caused by Fusarium graminearum) and stem rust (caused by Puccinia graminis) create large economic losses and threats to the world's food supplies (Strange and Scott, 2005). Conventional antifungals such as amphotericin $\mathrm{B}$, and azoles are still used to treat invasive fungal infections (Jarvis and Harrison, 2008) and fungicidal triazoles and strobulins continue to be used in massive quantities for wheat and other major crops (Fisher et al., 2012; Strange and Scott, 2005). Their effectiveness however grows increasingly limited by fungal resistance, host side effects, and ecosystem disturbances (Fisher et al., 2012; Strange and Scott, 2005). A consequence is a growing need to develop novel antifungals that are safe and effective.
Aminoglycosides are compounds having two or more amino sugars bound to an aminoacyclitol ring via glycosidic bonds. Many are used therapeutically against bacterial infections of humans and animals (Jarvis and Harrison, 2008). Among them, kanamycin A, produced by the soil microbe Streptomyces kanamyceticus, is one of the most successful (Umezawa et al., 1957; Begg and Barclay, 1995; Vakulenko and Mobashery, 2003). Kanamycin A is structurally based on neamine rings I and II with an attached ring III of O-6-linked kanosamine (Figure 1). Most bind to the prokaryotic $16 \mathrm{~S}$ rRNA in the decoding region A site, leading to the formation of defective cell proteins. Despite being mainly antibacterial, certain classical aminoglycosides are also found to inhibit crop pathogenic fungal-like heterokonts (Lee et al., 2005) and certain structurally unusual ones inhibit yeasts and protozoans (Wilhelm et al., 1978). Previously, we reported on a novel aminoglycoside analog of kanamycin B, FG08, with broad-spectrum antifungal properties that did not inhibit tested bacterial and mammalian cells (Figure 1) (Chang et al., 2010). FG08 differs from kanamycin B by substitution of a C8 alkyl 


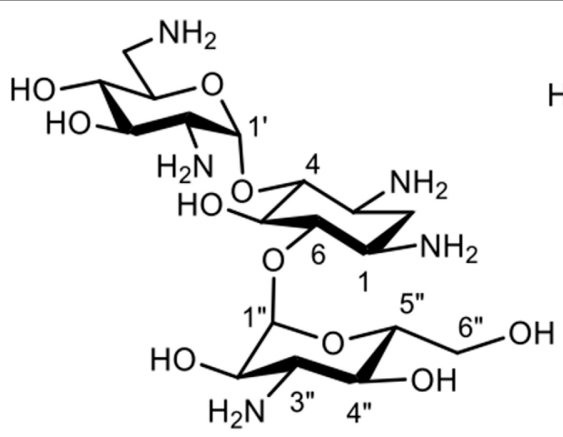

Kanamycin B

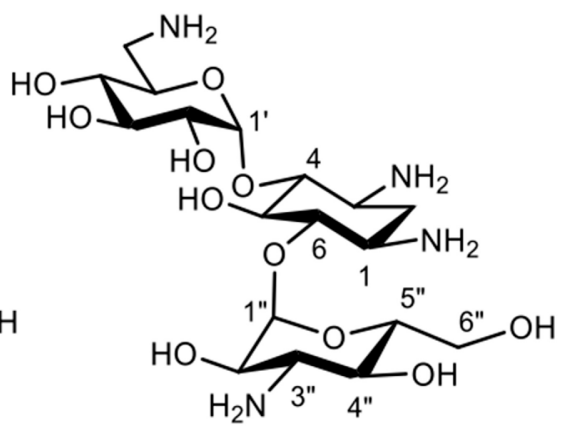

Kanamycin A
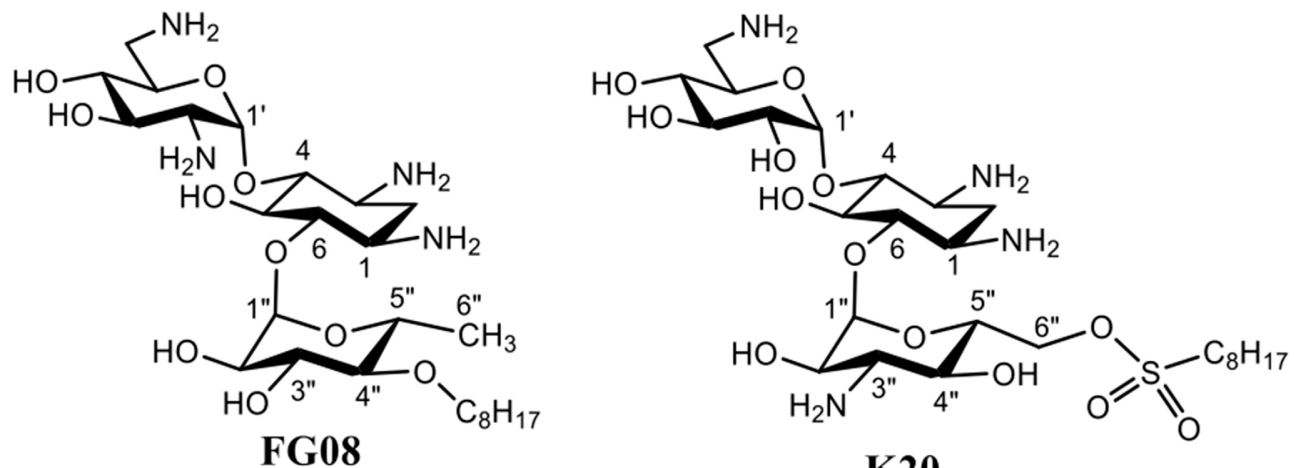

K20

FIGURE 1 | Structures of aminoglycosides FG08, kanamycin A, and K20.

chain at the $O-4$ "position of ring III to impart amphiphilic properties (Figure 1) (Chang et al., 2010). However, as a lead antifungal agent, FG08 is limited. Incorporation of the C8 alkyl chain at the kanamycin $\mathrm{B} O-4^{\prime \prime}$ position is difficult and the product yield is low. These shortcomings prompted the search for similar amphiphilic aminoglycosides using alternative synthetic approaches (Chang and Takemoto, 2014). From this effort, a novel and scalable aminoglycoside, K20, derived from kanamycin A was discovered that structurally resembled FG08 and that also possessed antifungal activity (Chang and Takemoto, 2012, 2014).

In the current study, K20's antifungal activities are more thoroughly examined, and its animal cell cytotoxicity and hemolytic capabilities were determined. K20's antifungal mechanism of action was determined using intact fungal cells and model lipid bilayer membranes. Like FG08, K20 exhibited growth inhibitory activities against a broad range of fungal species, but not against bacteria, and it was not hemolytic or cytotoxic at concentrations that inhibit fungi. K20's primary mechanism of action is shown to involve perturbation of plasma membrane permeability. Finally, in proof of concept experiments, K20 was observed to reduce the infectivity of $C$. neoformans in a preventive murine lung infection model,

\section{MATERIALS AND METHODS \\ K20 AND OTHER ANTIMICROBIALS}

K20 was synthesized from kanamycin A (Chang and Takemoto, 2014). Briefly, tetra-di-tert-butyl carbonate (Boc)-protected kanamycin A was stirred overnight with octanesulfonyl chloride in anhydrous pyridine at $0^{\circ} \mathrm{C}$. The mixture was then stirred at room temperature for 6 days, heated and incubated at $40^{\circ} \mathrm{C}$ for 1 day, and then concentrated to an oily crude product. Water $(500 \mathrm{~mL}$ ) was added to the residue material, and the mixture was stirred for 1 day. The suspension was extracted with ethyl acetate in a separatory funnel, washed twice with $1.0 \mathrm{~N} \mathrm{HCl}$ and once with water. The wash sequence was repeated 3 to 4 times, and the final organic layer was filtered and evaporated. The residue was treated with trifluoroacetic acid/dichloromethane (1:4) and stirred overnight. The solvents were removed, water added and the material evaporated to remove residual acid. The crude product was dissolved in water and washed repeatedly with ethyl acetate until the aqueous fraction was clear. The aqueous solution was concentrated and passed through a column of Dowex1X-8 (Cl-form). K20 in highly pure form was recovered (overall yield of $40 \%$ ) after evaporation and stored as a solid at $5^{\circ} \mathrm{C}$. K20 was characterized by ${ }^{1} \mathrm{H}$ NMR and ${ }^{13} \mathrm{C}$ NMR (using a Joel $300 \mathrm{MHz}$ NMR spectrometer) and mass spectrometry [using a Waters GCT (2008) High resolution mass spectrometer at the High Resolution Mass Spectrometry Facility, University of California, Riverside, USA]. Correlation Spectroscopy (COSY) and edited Heteronuclear Single Quantum Correlation (HSQC) were used for $\mathrm{H}-\mathrm{H}$ and $\mathrm{H}-\mathrm{C}$ correlation, respectively (see Supplementary Material). For bioactivity tests and mechanism of action studies, a $10 \mathrm{mg} / \mathrm{mL}$ stock solution was prepared in twice distilled water and stored at $5^{\circ} \mathrm{C}$. FG08 was synthesized as previously 
described (Chang et al., 2010), and kanamycin A was purchased (Changzhou Zhongtian Chemical Co. LTD., Changzhou, PRC).

\section{ORGANISMS AND CULTURE CONDITIONS}

Fusarium graminearum strain B4-5A was obtained from the Small Grain Pathology Program, University of Minnesota, Minneapolis MN, USA. E. coli TG1, S. aureus ATCC6538, M. luteus ATCC10240, C.albicans ATCC10231(azole-resistant), C. albicans ATCC64124 (azole-resistant), and C. albicans ATCC MYA-2876 (azole sensitive) were obtained from the American Type Culture Collection (Manassas, VA, USA). Saccharomyces cerevisiae strains W303C (MATa ade2 his3 leu2 trp1 ura3) and isogenic sphingolipid biosynthesis mutant strains W303- $\Delta$ syr2 (MATa ade2 his3 leu2 trp1 ura3 syr2 (sur2)::URA3), W303$\triangle$ elo3 (MATa ade2 his3 leu2 trp1 ura3 elo2::HIS3), and W303$\Delta$ syr4(ipt1)(MATa ade2 his3 leu2 trp1 ura3 syr4 (ipt1)::URA3) were previously described (Stock et al., 2000). Phenotypically, these mutants lack sensitivity to the antifungal syringomycin Ea membrane lipidic pore forming cyclic lipodespsipeptide (Stock et al., 2000). C. neoformans $\mathrm{H} 99$ was obtained from Dr. J. Perfect (Duke University Medical Center, Durham, NC, USA). C. neoformans 94-2586, C. neoformans 90-26, C. tropicalis 95-41,C. albicans 94-2181, C. albicans B-311, C. rugosa 95-967, C. pseudotropicalis YOGI, and C. lusitaniae 95-767 were obtained from the laboratory culture collection of Dr. Kevin Sorensen (Snow College, Ephraim, Utah, USA). Aspergillus flavus, and F. oxysporum were obtained from Dr. Bradley Kropp (Utah State University, Logan, UT, USA) and A. niger and Botrytis alcada were obtained from Dr. Claudia Nischwitz (Utah State University, Logan, UT, USA). Filamentous fungi and yeast strains were maintained on potato dextrose agar (PDA) and cultivated at $28^{\circ} \mathrm{C}$ in potato dextrose broth (PDB) or at $35^{\circ} \mathrm{C}$ with RPMI 1640 (with L-glutamine, without sodium bicarbonate (Sigma-Aldrich Chemical Co., St. Louis, MO, USA) buffered to $\mathrm{pH} 7.0$ with $0.165 \mathrm{M}$ morpholinepropanesulfonic acid (MOPS). Bacterial strains were grown at $37^{\circ} \mathrm{C}$ for $24 \mathrm{~h}$ on LuriaBertani (LB) medium (Sambrook et al., 1989) except for S. aureus ATCC6538 which was grown on Mueller-Hinton medium (Difco, BD, Franklin Lakes, NJ, USA).

\section{FUNGAL GROWTH INHIBITION ASSAYS}

Minimal inhibitory concentration (MIC) and minimal fungicidal concentration (MFC) values of K20 against yeast strains were determined using microbroth dilution assays in 96-well uncoated polystyrene microtiter plates (Corning Costar, Corning, NY, USA) as described in the M27-A3 reference methods of the Clinical and Laboratory Standards Institute (CLSI) (formerly the National Committee for Clinical Laboratory Standards) (NCCLS, 2002) with minor modifications. Modifications included growing yeast cell inocula in RPMI 1640 medium for $48 \mathrm{~h}$ at $35^{\circ} \mathrm{C}$ and suspending fresh-grown inocula to a concentration of $5 \times 10^{4}$ cells $/ \mathrm{mL}$ (determined by hemocytometer cell counting) in fresh RPMI 1640 for the assays. All yeast cell suspensions $(100 \mu \mathrm{L})$ containing 0.48 to $250 \mathrm{mg} / \mathrm{L}$ of serial diluted $\mathrm{K} 20$ except for C. neoformans (with $0.25-128 \mathrm{mg} / \mathrm{L}$ of $\mathrm{K} 20$ ) were added to the wells of a 96-well microtiter plate and incubated for $48 \mathrm{~h}$ at $35^{\circ} \mathrm{C}$. Controls were no yeast cells and no K20 added to separate wells. MFC values were determined as the occurrence of fewer than 3 colonies after plating $5 \mu \mathrm{L}$ of the cleared microtiter plate wells from MIC tests on Sabouraud's dextrose agar medium (Difco, BD, Franklin Lakes, NJ, USA). Each test was performed in triplicate. For in vitro antifungal activities against $F$. graminearum B4-5A, F. oxysporum, A. flavus, A. niger, and Botrytis alcada, spores were prepared as described previously (Lay et al., 2003). Spores were isolated from sporulating cultures growing in PDB medium by filtration through sterile glass wool. Microbroth dilution assays for determination of MICs were conducted using the M38-A2 protocols of the CLSI (NCCLS, 2008) with minor modification. Serial dilutions of K20 were made in uncoated polystyrene 96-well plates in the range of $0.48-250 \mathrm{mg} / \mathrm{L}$ using RPMI 1640 medium and spore suspensions were added to make a final concentration of $5 \times 10^{5} \mathrm{CFU} / \mathrm{mL}$. The plates were incubated at $35^{\circ} \mathrm{C}$ for $72 \mathrm{~h}$ except for tests with $F$. graminearum B4-5A which were incubated for $48 \mathrm{~h}$. MIC values were determined as the lowest concentration of compounds showing optically clear solutions by visual inspection of the plate wells (NCCLS, 2002, 2008). Each test was performed in triplicate. Disk diffusion assays of yeast strains were performed as previously described (Chang et al., 2010). Cell suspensions $(0.5 \mathrm{~mL})$ were spread-plated onto potato-dextrose agar (PDA) medium and air-dried for $5 \mathrm{~min}$. Eight microliter aliquots of $\mathrm{K} 20(1-10 \mathrm{mg} / \mathrm{mL}$ in water) were applied to $0.6 \mathrm{~cm}$ diameter paper disks placed on the agar surfaces, and the plates were incubated for $24-48 \mathrm{~h}$ at $28^{\circ} \mathrm{C}$. These amounts of $\mathrm{K} 20$ provided visible and measurable zones of growth inhibition around the disks as previously determined for FG08 (Chang et al., 2010).

\section{BACTERIAL GROWTH INHIBITION ASSAYS}

The in vitro effects of $\mathrm{K} 20$ on the growth of bacterial species E. coli TG1, M. luteus ATCC10240 and S. aureus ATCC6538 were assayed in 96-well uncoated polystyrene microtiter plates and MICs were determined using CLSI protocols with modification (NCCLS, 1993). Cells were grown overnight in Luria-Bertani medium and diluted to a concentration of $1 \times 10^{4} \mathrm{CFU} / \mathrm{mL}$. Ten microliter of the diluted overnight culture were then added to $190 \mu \mathrm{L}$ of Luria-Bertani medium containing K20 at concentrations ranging between 0.48 and $250 \mathrm{mg} / \mathrm{L}$. Controls were bacterial cells only and no K20 added to separate wells. The plates were incubated at $37^{\circ} \mathrm{C}$ without shaking for $24 \mathrm{~h}$ before determination of MICs. Experiments were performed in triplicate.

\section{ANTIFUNGAL CARRYOVER AND TIME-KILL CURVE ANALYSES}

Antifungal carryover was determined as described by Klepser et al. (2000). C. neoformans $\mathrm{H} 99$ cell suspensions were prepared in sterile water to yield $1 \times 10^{5} \mathrm{CFU} / \mathrm{mL}$. One hundred microliter of each suspension was added to $900 \mu \mathrm{L}$ of sterile water (control) or to sterile water containing K20 at concentrations of 2 , 4 , and $8 \mathrm{mg} / \mathrm{L}$, equal to $0.5,1$, and 2 times the MIC, respectively. Immediately after addition of fungal suspension, $100 \mu \mathrm{L}$ of suspension was removed and spread-plated on PDA for colony count determination. Antifungal carryover was indicated when a reduction in colony counts of $>25 \%$ compared to controls was observed. Time-kill curves were generated as described (Klepser et al., 2000) with modifications. Colonies from 24 to $48 \mathrm{~h}$ cultures were suspended in $9 \mathrm{~mL}$ sterile water and adjusted to $1 \times 10^{8}$ $\mathrm{CFU} / \mathrm{mL}$. One milliliter of the adjusted fungal suspension was 
then added to $1 \mathrm{~L}$ of either PDB growth medium alone (control) or a solution of PDB and K20 at concentrations of 2, 4 or $8 \mathrm{mg} / \mathrm{L}$. Fifty milliliter aliquots of culture suspensions in $125-\mathrm{mL}$ capacity Erlenmeyer flasks were incubated in a water bath shaker (Model G76, New Brunswick Scientific, NJ, USA) with agitation at $35^{\circ} \mathrm{C}$. At $0,4,9,24$, and $48 \mathrm{~h}, 100 \mu \mathrm{L}$ aliquots were removed from each solution and serially diluted 10 -fold in sterile water. One hundred microliter volumes of each dilution were spread on agar surfaces of potato dextrose agar [PDB containing agar $(2 \%$, wt/vol $)$ ] plates to allow growth. Colony counts were determined after incubation for $48 \mathrm{~h}$. The experiment was performed in triplicate. The lower limit for accurate and reproducible quantification was 50 CFU/mL (Klepser et al., 2000).

\section{HEMOLYTIC ACTIVITY}

Hemolytic activity was determined using previously described methods (Dartois et al., 2005) with modification. Sheep erythrocytes were obtained by centrifuging sheep whole blood at $1000 \times$ $g$, washing four times with phosphate-buffered saline (PBS), and resuspending in PBS to a final concentration of $10^{8}$ erythrocytes $/ \mathrm{mL}$. The erythrocyte suspension $(80 \mu \mathrm{L})$ was added to wells of a 96-well polystyrene microtiter plate containing $20 \mu \mathrm{L}$ of serially diluted $\mathrm{K} 20(1.0-0.015 .1 \mathrm{~g} / \mathrm{L})$ in water. The plate was incubated at $37^{\circ} \mathrm{C}$ for $60 \mathrm{~min}$. Wells with added deionized water and Triton X-100 (1\% v/v) served as negative (blank) and positive controls, respectively. The $\mathrm{A}_{490}$ values of each well were measured using a BioTek Synergy 4 microplate reader (BioTek Instruments Inc., Winooski, VT, USA). Percent hemolysis was calculated using the following equation: $\%$ hemolysis $=\left[\left(\mathrm{A}_{490}\right.\right.$ of sample $)-\left(\mathrm{A}_{490}\right.$ of blank $)] \times 100 /\left(\mathrm{A}_{490}\right.$ of positive control $)$. Fifty percent hemolysis $\left(\mathrm{HC}_{50}\right)$ values were calculated as $\mathrm{K} 20$ concentrations that lyse $50 \%$ of the erythrocytes.

\section{IN VITRO CYTOTOXICITY ASSAYS}

Cytotoxicity assays were performed as previously described for FG08 (Shrestha et al., 2013). The C8161.9 melanoma cell line was a gift from Dr. Danny R. Welch, University of Kansas, Lawrence, KS (USA). Fibroblast cell line NIH3T3 (ATCC ${ }^{\circledR}$ CRL-1658 ${ }^{\mathrm{TM}}$ ) was obtained from the American Type Culture Collection (Manassas, VA, USA.)

C8161.9 cells were grown in DMEM/Ham's F12 (1:1) containing $10 \%$ fetal bovine serum (FBS). NIH3T3 cells were grown in DMEM (high glucose) medium containing 10\% FBS in Corning Cell Bind flasks. The confluent cells were then trypsinized with $0.25 \%, \mathrm{w} / \mathrm{v}$ trypsin and resuspended in fresh medium (DMEM). The cells were transferred into 96-well uncoated polystyrene microtiter plates at a density of $2 \times 10^{5}$ cells $/ \mathrm{mL}$. K20 was added at final concentrations of 10,20,50,100, and $250 \mathrm{mg} / \mathrm{L}$ or an equivalent volume of sterile double distilled water (negative control). The cells were incubated for $24 \mathrm{~h}$ at $37^{\circ} \mathrm{C}$ with $5 \% \mathrm{CO}_{2}$ in a humidified incubator. To evaluate cytotoxicity, each well was treated with $10 \mu \mathrm{L}$ of 3-(4,5-dimethylthiazol-2yl)-2,5-diphenyltetrazolium bromide (MTT) (Sigma-Aldrich, St. Louis, MO USA) for $4 \mathrm{~h}$. In living cells, mitochondrial reductases convert the MTT tetrazolium to formazan, which precipitates. Formazan was dissolved adding 10\% (wt/vol) NaDodSO4 in $0.01 \mathrm{M} \mathrm{HCl}$ and quantified at $\mathrm{A}_{570}$ using a BioTek Synergy4 microplate reader (BioTek Instruments Inc., Winooski, VT, USA). Triton $\mathrm{X}-100^{\circledR}(1 \%, \mathrm{vol} / \mathrm{vol})$ gave complete loss of cell viability and was used as the positive control. The ratios of $A_{570}$ values for K20 treated cells to the $A_{570}$ values for the untreated cells were used to calculate \% cell survival. Standard deviations were determined from data sets of three separate experiments.

\section{MEMBRANE PERMEABILIZATION}

C. neoformans $\mathrm{H} 99\left(5 \times 10^{5} \mathrm{CFU} / \mathrm{mL}\right)$ or F. graminearum $(5 \times$ $10^{5}$ conidia/mL) were grown for $18 \mathrm{~h}$ in PDB with continuous agitation. Aliquots $(500 \mu \mathrm{L})$ were taken and centrifuged for $2 \mathrm{~min}$ at $10,000 \times g$. The fungal pellet was suspended in $10 \mathrm{mM}$ HEPES, pH 7.4, centrifuged again, and suspended in $500 \mu \mathrm{L}$ distilled water (Chang et al., 2010). C. neoformans H99 cells were exposed to 4, 8, and $25 \mathrm{mg} / \mathrm{L} \mathrm{K20}$ and F. graminearum B4-5A hyphae to $7.8,15.6$, and $32 \mathrm{mg} / \mathrm{L} \mathrm{K} 20$ for $1 \mathrm{~h}$ at $28^{\circ} \mathrm{C}$ with continuous agitation. The $\mathrm{K} 20$ treated fungi were assessed $10 \mathrm{~min}$ after addition of fluorescein isothiocyanate (FITC) $(10 \mathrm{mg} / \mathrm{mL}$ stock in acetone) (Sigma-Aldrich Chemical Co., St. Louis, MO, USA) to $6 \mathrm{mg} / \mathrm{L}$ as previously described (Shrestha et al., 2013) with slight modification. Negative (water) and positive (Triton X-100 ${ }^{\circledR} 1 \%$, $\mathrm{vol} / \mathrm{vol}$ ) treatment controls were also prepared. Glass slides were prepared with $10 \mu \mathrm{L}$ of each mixture and observed in dark-field and fluorescence (using an Olympus MWIB filter, excitation, and emission wavelength 488-512 nm) modes with an Olympus IX81 fluorescence microscope (Olympus, Center Valley, PA, USA). Dye uptake of $C$. neoformans $\mathrm{H} 99$ cells was quantitated as previously described (Shrestha et al., 2013) and of F. graminearum B4-5A by qualitative estimates from visual inspection. Data were obtained from at least three independent experiments.

\section{CALCEIN RELEASE FROM SMALL UNILAMELLAR VESICLES (SUVs)}

Lipids (from Sigma-Aldrich Chemical Co., St. Louis, MO USA) were phosphatidylcholine from Glycine $\max (\mathrm{PC}), \mathrm{L}-\alpha-$ phosphatidylethanolamine from E. coli (PE), L- $\alpha$ - phosphatidylinositol (Na salt) from G. $\max (\mathrm{PI})$, and ergosterol. Model lipid bilayer membrane SUVs were prepared by dissolving mixtures of lipids in chloroform/methanol (2:1, vol/vol). The mixtures were PC, PE, PI, and ergosterol (5:4:1:2 ratios by wt) and PC and ergosterol (10:1 ratio by wt) to mimic the lipid compositions of fungal plasma membranes (Makovitzki et al., 2006; Lee et al., 2009). The organic solvents were evaporated with nitrogen gas and the lipid mixtures dried under vacuum. The dried lipid films were rehydrated in HEPES buffer (10 mM HEPES, $150 \mathrm{mM} \mathrm{NaCl}, \mathrm{pH}$ 7.4) and sonicated to generate SUVs with lipid concentrations at $10 \mathrm{mg} / \mathrm{mL}$. Lipid films were prepared as described above and were suspended in $10 \mathrm{mM}$ HEPES, $150 \mathrm{mM} \mathrm{NaCl}, \mathrm{pH} 7.4$, and $60 \mathrm{mM}$ calcein (self-quenching concentration) (Makovitzki et al., 2006). Liposome suspensions were sonicated for $2 \mathrm{~min}$ using a sonicator (Sonicator $^{\mathrm{TM}}$ Heat System, W-220F, Ultrasonics, NY, USA). The free calcein was removed by gel filtration through a Sephadex G50 column. K20 at concentrations of 31.3 [at or near the MICs for most fungi tested (Table 1)], 62.2, and $125 \mathrm{mg} / \mathrm{L}$ (2- and 4fold higher, respectively, than the initial concentration) was added to the calcein-loaded SUV suspensions (lipid concentration of 6 to $10 \mu \mathrm{M}$ ), and calcein leakage was followed by measuring fluorescence using a BioTek Synergy HT microplate reader at 
Table 1 | Minimal inhibitory concentrations of K20 and kanamycinA against bacteria and fungi.

\begin{tabular}{|c|c|c|c|c|}
\hline \multirow[t]{2}{*}{ Organism } & \multicolumn{4}{|c|}{$\operatorname{MIC}(\mathrm{mg} / \mathrm{L})^{\mathrm{a}}$} \\
\hline & K20 & Kanamycin & ITC & FLC \\
\hline \multicolumn{5}{|l|}{ YEASTS } \\
\hline C. neoformans H99 & $3.9-7.8$ & $>125^{b}$ & 1.56 & 1.56 \\
\hline C. neoformans 94-2586 & $3.9-7.8$ & $>125^{b}$ & 0.06 & 1.56 \\
\hline C.neoformans 90-26 & $3.9-7.8$ & $>250$ & 0.37 & $>0.195$ \\
\hline C. pseudotropicalis YOGI & 15.6 & $>250$ & $0.125-0.8$ & $n d^{c}$ \\
\hline C. lusitaniae 95-767 & $>7.8$ & $>250$ & 0.2 & 1.56 \\
\hline C. rugosa 95-967 & 15.6 & $>250$ & 0.12 & $>0.78$ \\
\hline C. tropicalis $95-41$ & 15.6 & $>250^{b}$ & $>25$ & $>25$ \\
\hline C. albicans 10231 & 15.6 & $>250^{b}$ & 0.75 & 25 \\
\hline C. albicans $64124(\mathrm{R})^{\mathrm{d}}$ & 31.3 & $>500^{\mathrm{b}}$ & $>64$ & $>200$ \\
\hline C. albicans MYA $2876(\mathrm{~S})^{\mathrm{e}}$ & 15.6 & $>250$ & $>2$ & 1.56 \\
\hline C. albicans B-311 & $>7.8$ & $>250$ & $16-32$ & $>25$ \\
\hline C. albicans 94-2181 & $>7.8$ & $>250$ & $>8-16$ & $>12.5$ \\
\hline C. parapsilosis $(\mathrm{R})^{\mathrm{d}}$ & $15.6-31.3$ & $>250$ & 0.5 & $>16$ \\
\hline C. parapsilosis $(\mathrm{S})^{\mathrm{e}}$ & 15.6 & $>250$ & 0.015 & 0.12 \\
\hline \multicolumn{5}{|l|}{ FILAMENTOUS FUNGI } \\
\hline F. graminearum B-4-5A & 7.8 & $>125^{b}$ & nd & nd \\
\hline F. oxysporum & 31.3 & $>250^{b}$ & nd & nd \\
\hline A. flavus & 300 & $>250$ & 0.125 & nd \\
\hline A. niger & $>150$ & $>250$ & nd & nd \\
\hline B. alcada & 15.6 & & nd & \\
\hline \multicolumn{5}{|l|}{ BACTERIA } \\
\hline E. coli TG1 & $125-250$ & $1.95^{\mathrm{b}}$ & & \\
\hline S. aureus ATCC 25923 & 250 & $<0.98^{b}$ & & \\
\hline M. luteus ATCC 10240 & 62.5 & $1.95^{\mathrm{b}}$ & & \\
\hline
\end{tabular}

a Microbroth dilution assays were performed at least twice, and each in triplicate.

${ }^{b}$ Determined with kanamycin $A$; all others were determined with kanamycin $B$.

${ }^{c}$ not determined.

${ }^{d}(R)$ Resistant.

${ }^{e}(S)$ Sensitive.

an excitation wavelength of $488 \mathrm{~nm}$ and emission wavelength of $520 \mathrm{~nm}$. Complete $(100 \%)$ dye release was obtained by addition of Triton $\mathrm{X}-100^{\circledR}(1 \%$, vol/vol). The dye-leakage percentage was calculated as follows: $\%$ dye leakage $=100 \times\left(F-F_{0}\right) /\left(F_{\mathrm{t}}-F_{0}\right)$, where $F$ represents the fluorescence intensity 2 min after K20 addition, and $F_{0}$ and $F_{\mathrm{t}}$ represent the fluorescence intensity without K20 and with Triton $\mathrm{X}-100^{\circledR}(1 \%$, vol/vol), respectively (Zhang et al., 2001).

\section{CRYPTOCOCCOSIS PREVENTIVE MURINE LUNG INFECTION MODEL}

In vivo efficacy of $\mathrm{K} 20$ treatment was evaluated in a proof of concept study using preventive murine lung infection model as previously described (Searles et al., 2013). For this study RAG ${ }^{-/-}$ mice lacking both $\mathrm{T}$ and $\mathrm{B}$ cells due to a defect in the recombination antigen gene were obtained from Jackson Laboratories (Bar Harbour, ME, USA) and maintained at the Montana State University Animal Resource Center (Bozeman, MT, USA). The studies conformed to NIH guidelines and were approved by the Montana State University IACUC and biosafety committee (approval number: (2014-17 and 027-2013). Three treatment groups each consisting of five $\mathrm{RAG}^{-/-}$mice were compared. Group A received one dose of $100 \mu \mathrm{L}$ of $200 \mathrm{mg} / \mathrm{L} \mathrm{K20}$ in PBS (10 $\mathrm{mM}$ phosphate, $2.7 \mathrm{mM} \mathrm{KCl}$, and $137 \mathrm{mM} \mathrm{NaCl}, \mathrm{pH}$ 7), group B received $100 \mu \mathrm{L}$ of $200 \mathrm{mg} / \mathrm{L} \mathrm{K} 20$ mixed with $C$. neoformans H99 cells $\left(5 \times 10^{3}\right.$ cells $\left./ \mathrm{mL}\right)$, and group $\mathrm{C}$ received cells mixed in PBS only by intratracheal instillation. K20 doses averaged $0.824 \mathrm{mg} / \mathrm{kg}$ body weight. Mice were monitored for signs of distress and their weights recorded daily over the course of infection. Weight loss or gain was plotted as percent of weight change. Mice were euthanized if weight loss exceeded 25\%. At day 15 post-infection, lungs were removed, suspended in $5 \mathrm{~mL}$ PBS and homogenized by extrusion through a $100 \mu \mathrm{m}$ mesh steel screen. Lung cryptococcal burden was assessed by plating $100 \mu \mathrm{L}$ of the homogenized suspension onto yeast extract-peptone-dextrose agar plates (26) at 1:10, 1:100, and 1:1000 dilutions in PBS, incubated for 3 days, and colonies counted. For microscopic examination, homogenates were suspended in $10 \mathrm{~mL}$ of PBS and a 1:20 dilution of the homogenate was spun onto glass slides using a Cytospin 4 centrifuge (ThermoFisher, NJ, USA). Slides were fixed in methanol for $3 \mathrm{~min}$ followed by Diff-Quik ${ }^{\mathrm{TM}}$ (Siemens Healthcare Diagnostics Inc. Newark, DE USA) staining for 3 min each in solution 1 and 2. Stained yeast cells were visualized with a Nikon 80i Eclipse upright microscope as large purple colored cells surrounded by opaque halos. The experiments were performed twice. Data were statistically analyzed and $P$-values determined by one-way (lung burden experiments) and Two-Way (weight change experiments) ANOVA methods using GraphPad Prism software (La Jolla, CA, USA).

\section{RESULTS}

\section{IN VITRO ANTIFUNGAL AND ANTIBACTERIAL ACTIVITIES}

K20 generally displayed antifungal activities against yeasts (e.g., S. cerevisiae strain W303C) and filamentous fungi (e.g., F. graminearum B4-5A), but no or little activity against either Gram negative (e.g., E. coli TG1) or Gram-positive (e.g., S. aureus ATCC 6538) bacteria (Figure 2). In microbroth dilution assays with RPMI 1640 medium, K20 inhibited the growth of most fungi tested (Table 1). MICs ranged from 4 to $31.3 \mathrm{mg} / \mathrm{L}$ for yeasts and $7.8-300 \mathrm{mg} / \mathrm{L}$ for filamentous fungi (Table 1). K20 MICs with yeasts were uniformly higher than MICs achieved with itraconanzole and fluconazole except with azole resistant strains, C. albicans strains 64124 and B-311 and C. tropicalis 95-41. MFC values determined for C. albicans strains MYA 2876 and 64124 were equal to or 2-fold higher than the corresponding MIC values (data not shown). Among the yeasts tested, C. neoformans strains were consistently the most susceptible to K20. Among filamentous fungi tested, F. graminearum B4-5A was the most susceptible to K20; A. flavus and A. niger were the least susceptible. Bacterial species E. coli TG1, M. luteus ATCC10240 and S. aureus ATCC6538 growing in LB medium were less susceptible to K20. The antibacterial MICs were 65 to 125 -fold higher than shown by kanamycin A (Table 1).

\section{ANTIFUNGAL CARRYOVER AND TIME-KILL ANALYSES}

With C. neoformans H99, no antifungal carryover was observed in the procedures used at $0.5,1$, and $2 \times$ the K20 MIC. The time kill curves for K20 and C. neoformans H99, showed that 


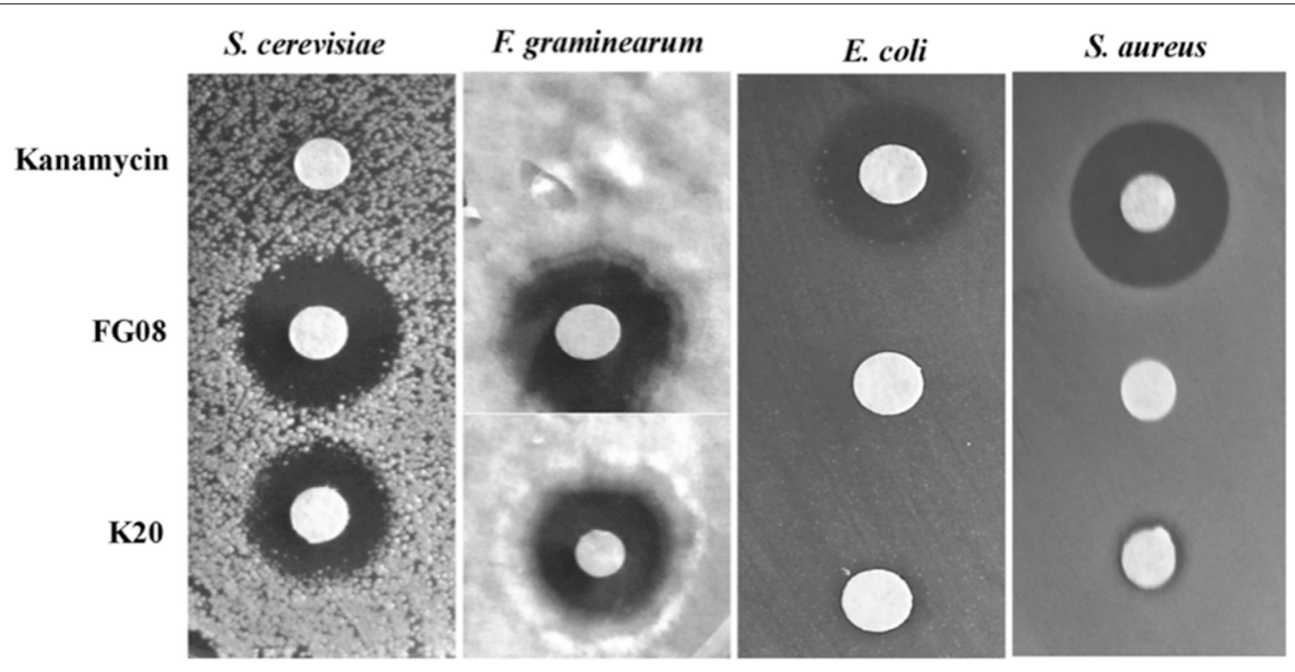

FIGURE 2 | Antimicrobial activities of K20, FG08, and kanamycin A. Disk agar diffusion assays show that K20 and FG08 are antifungal, but not antibacterial. Kanamycin $A$ is antibacterial, but not antifungal. Ten $\mu \mathrm{L}$ aliquots of K20, FG08, and kanamycin A solutions were applied to paper disks $10.6 \mathrm{~cm}$ diameter) on surfaces of PDA and LB agar at concentrations of 10 and $5 \mathrm{mg} / \mathrm{mL}$, respectively, and with spread-plated fungal (S. cerevisiae strain W303C and F. graminearum B4-5A) and bacterial (E. coli TG1and S. aureus ATCC 6538) cultures, respectively.

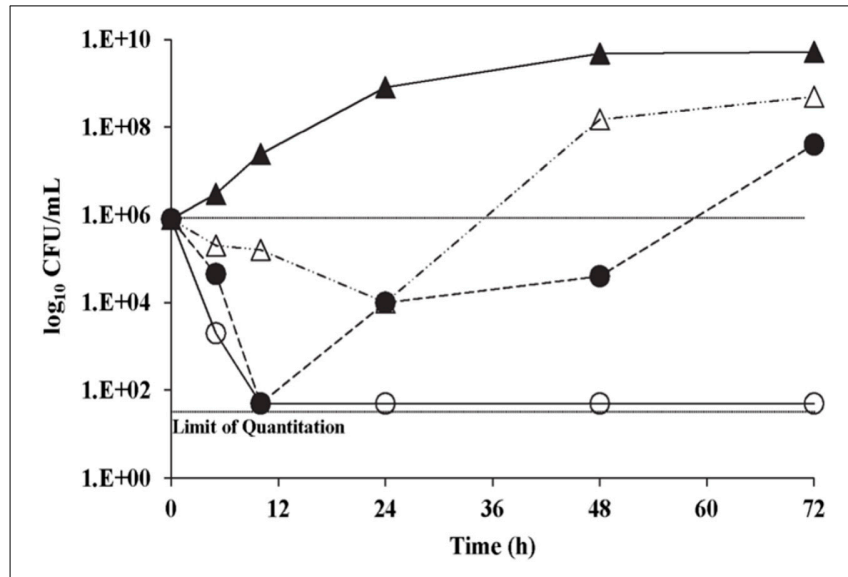

FIGURE 3 | Time kill curves for $\boldsymbol{C}$. neoformans $\mathrm{H} 99$ exposed to K20. Cultures were exposed to $\mathrm{K} 20$ at $2 \mathrm{mg} / \mathrm{L}$ (open triangles), $4 \mathrm{mg} / \mathrm{L}$ (filled circles), and $8 \mathrm{mg} / \mathrm{L}$ (open circles) or to no K20 (filled triangles).

the MIC level of $\mathrm{K} 20(4 \mathrm{mg} / \mathrm{L})$ reduced the $\mathrm{CFU} / \mathrm{mL}$ by $\geq 2 \log _{10}$ units (Figure 3). However, a $2 \times$ MIC level $(8 \mathrm{mg} / \mathrm{L})$ of $\mathrm{K} 20$ was required to achieve a fungicidal effect (100\% killing). At $4 \mathrm{mg} / \mathrm{L}$ $(1 \times$ MIC), K20 exhibited a fungistatic effect after $10 \mathrm{~h}$ incubation.

\section{SHEEP ERYTHROCYTE HEMOLYSIS}

K20 lysed $<40 \%$ of sheep erythrocytes at $500 \mathrm{mg} / \mathrm{L}$ (Figure 4) a concentration that is $>50$-fold higher than the antifungal $\mathrm{MIC}$ against $C$. neoformans $\mathrm{H} 99$. The $\mathrm{HC}_{50}$ value for $\mathrm{K} 20$ was $>500 \mathrm{mg} / \mathrm{L}$. Kanamycin A did not show hemolytic activity against sheep erythrocytes (data not shown).

\section{ANIMAL CELL CYTOTOXICITY}

K20 showed no or low toxicity against C8161.9 and NIH3T3 cells at concentrations up to $250 \mathrm{mg} / \mathrm{L}$ (Figure 5). The $50 \%$ inhibitory

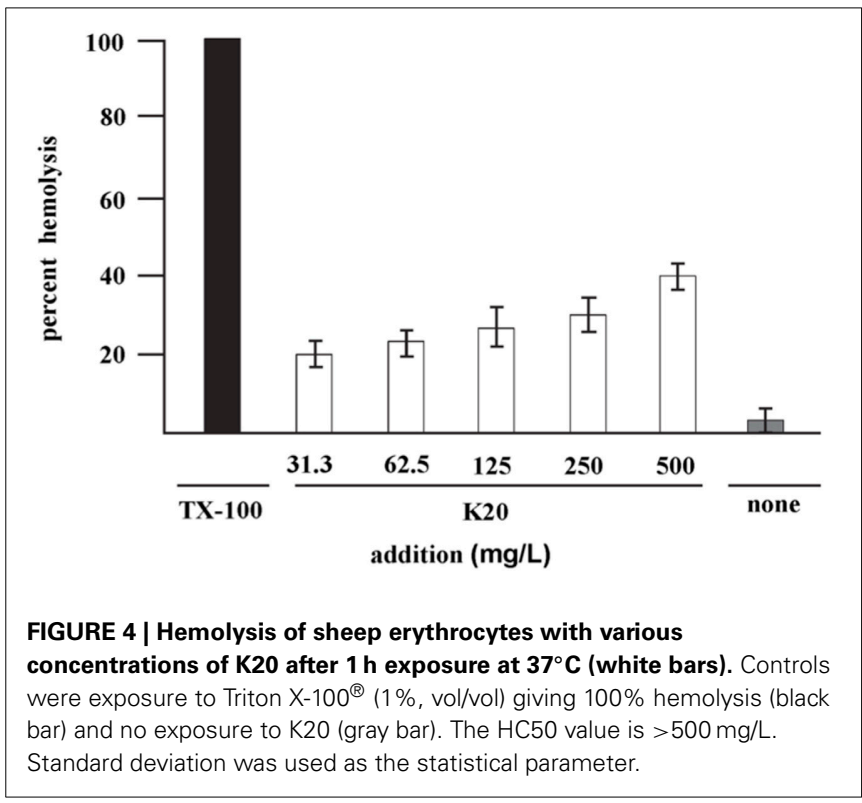

concentrations $\left(\mathrm{IC}_{50}\right)$ of $\mathrm{K} 20$ for both C8161.9 and NIH3T3 cells were $>500 \mathrm{mg} / \mathrm{L}$ (Figure 5), and at least 31-fold higher than the antifungal MIC against C. neoformans H99 (Table 1).

\section{FLUORESCENT DYE UPTAKE}

FITC dye was used to assess the membrane-perturbation effects of $\mathrm{K} 20$ on the plasma membrane of C. neoformans $\mathrm{H} 99$ and F. graminearum. FITC traverses cell surface membranes damaged or permeabilized by external agents and concentrates intracellularly to impart green fluorescence (Grilley et al., 1998; Mangoni et al., 2004). For C. neoformans H99, K20 at 8 and $25 \mathrm{mg} / \mathrm{L}$ caused FITC staining of 64 and $100 \%$ of the cells, respectively, and $<5 \%$ when exposed to kanamycin A (50 mg/L) (Figure 6). Untreated 
cells were negligibly stained ( $<2 \%)$. With F. graminearum B4-A5 hyphae, quantitation of the number of FITC stained cells was difficult because of its multinucleated cell structure. Qualitatively however, 15.6 and $32 \mathrm{mg} / \mathrm{L} \mathrm{K} 20$ were observed to cause a high

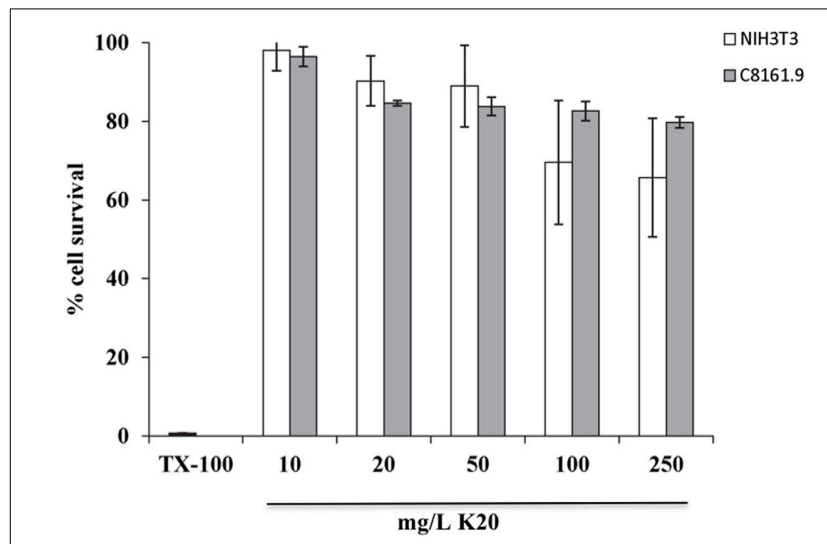

FIGURE 5 | Toxicities of NIH3T3 mouse fibroblast cells (white bars) and C8161.9 melanoma cells (gray bars) with $24 \mathrm{~h}$ exposure to $\mathrm{K} 20$ at

various concentrations. Positive control $(0 \%$ cell survival) was provided by treatment with Triton $\mathrm{X} 100^{\circledR}(1 \%$, vol/vol) (black bar). degree of FITC cell staining compared to exposure to $50 \mathrm{mg} / \mathrm{L}$ kanamycin A that gave essentially no visible staining of hyphae (Figure 7).

\section{SUV CALCEIN RELEASE}

K20 showed dose- dependent release of calcein from model lipid bilayer membrane SUVs that mimic fungal plasma membranes. Within $15 \mathrm{~min}, \mathrm{~K} 20$ at $31.2 \mathrm{mg} / \mathrm{L}$ caused $30 \%$ calcein leakage from SUVs composed of PC, PE, PI, and ergosterol (5:4:1:2 by wt) and of PC and ergosterol (7:3 by wt) (Figure 8). At $62.5 \mathrm{mg} / \mathrm{L}$, K20 caused $70-80 \%$ leakage from both types of SUVs within $15 \mathrm{~min}$ (Figure 8). SUVs without added K20 or treated with Triton $\mathrm{X}-100{ }^{\circledR}$ showed $<10$ or $100 \%$ calcein leakage, respectively.

\section{SUSCEPTIBILITY OF S. CEREVISIAE SPHINGOLIPID BIOSYNTHETIC MUTANTS}

Fungal cell surface sphingolipids influence the inhibitory activities of several amphiphilic, membrane interacting antifungal compounds (Grilley et al., 1998; Stock et al., 2000; Thevissen et al., 2003, 2012; Sugimoto et al., 2004). Among these compounds is syringomycin E (Segre et al., 1989) which resembles K20 in size ( $<1500$ daltons) and structural features of hydrophilic domains rich in hydroxyl and amino groups and hydrophobic

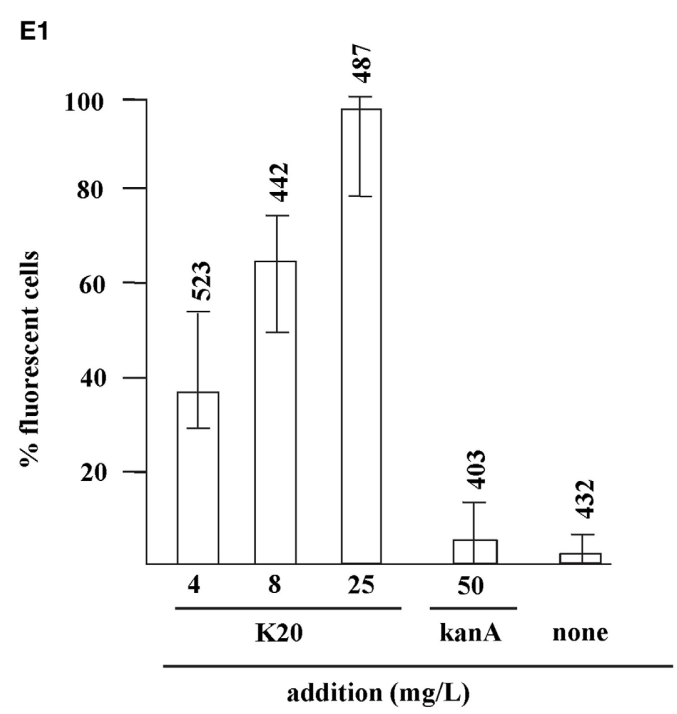

FIGURE 6 | Dose-dependent membrane perturbation effects of K20 on C. neoformans H99. FITC dye uptake without (A1,A2) and with K20 (4 mg/L) (B1,B2), (8 mg/L) (C1,C2), and (25 mg/L) (D1,D2) exposure for $10 \mathrm{~min}$.

Bright-field images $(\mathbf{A} \mathbf{1}, \mathbf{B 1}, \mathbf{C 1}, \mathbf{D} \mathbf{1})$ are compared with fluorescence images (A2,B2,C2,D2). Bar length is $10 \mu \mathrm{m}$. (E1) Shows dose-dependent effects of

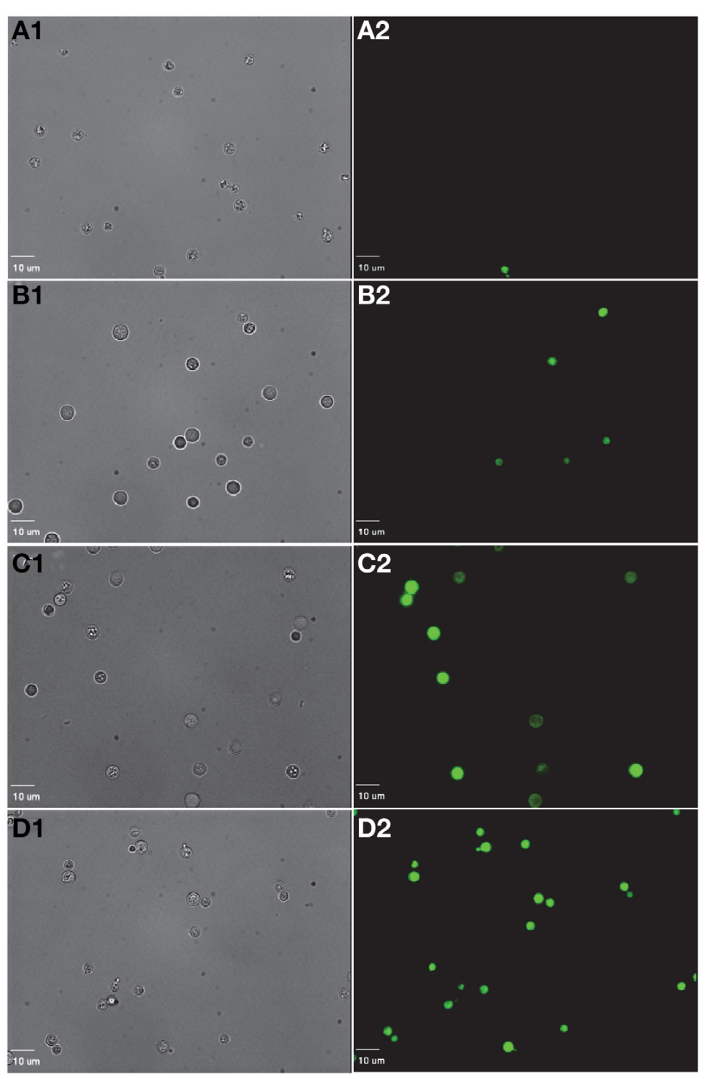

K20 on FITC dye uptake and effects of kanamycin A and no treatment Triton $X-100^{\circledR}(1 \%$, vol/vol) gave $100 \%$ dye influx (data not shown). The error bars show SD from analyses of 10 separate microscopic image fields randomly selected from at least two separate experiments. Numbers above the range bars indicate the number of cells analyzed. 


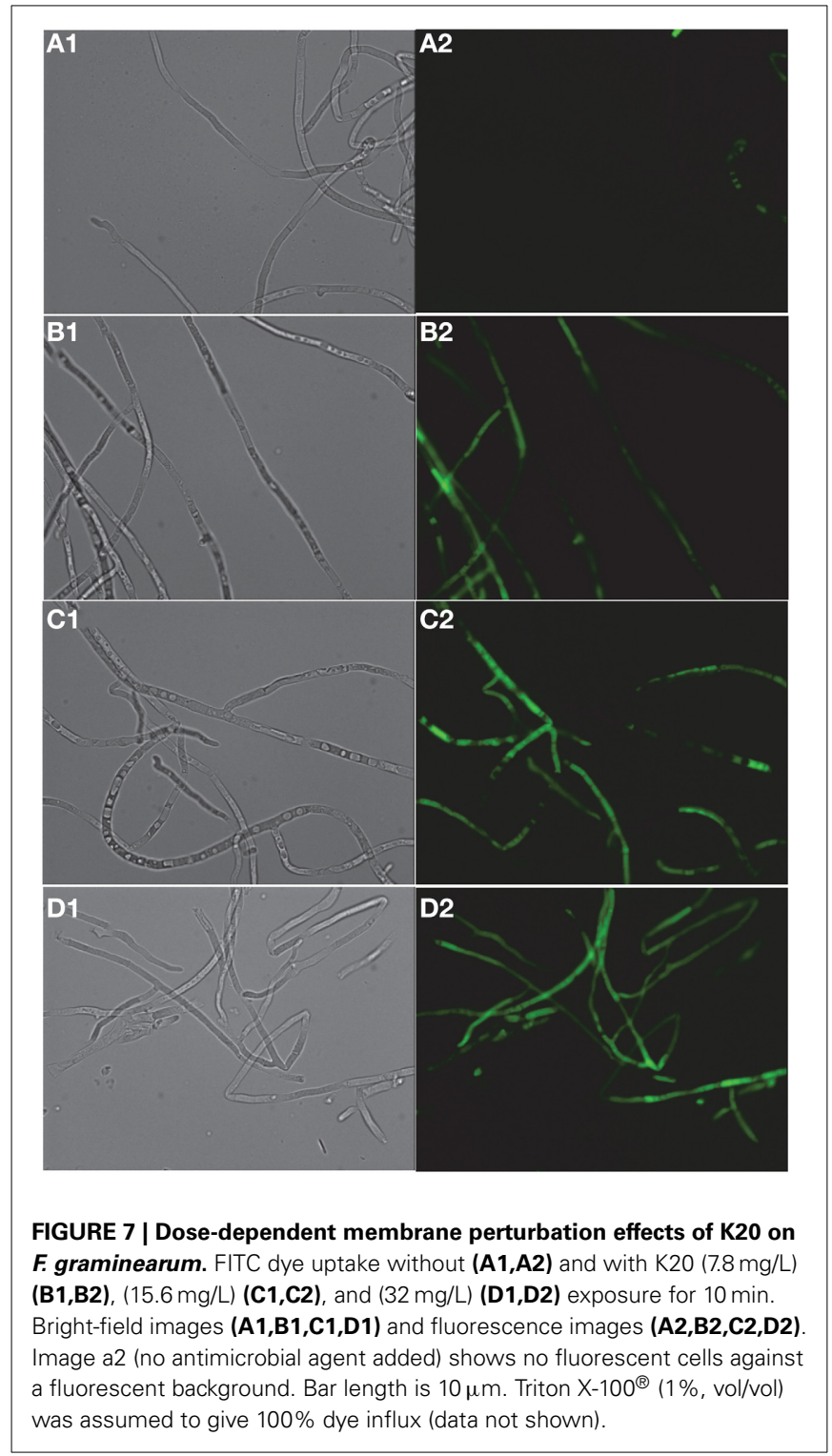

domains composed of alkyl chains. Fungal mutants with aberrations in sphingolipid structure or composition have been used to reveal the roles of these lipids in antifungal mechanism of action (Grilley et al., 1998; Stock et al., 2000; Ferket et al., 2003; Thevissen et al., 2003, 2012). Therefore, syringomycin E-resistant $S$. cerevisiae mutant strains with lipid defects caused by single gene disruptions in specific sphingolipid biosynthetic genes were examined for susceptibility to K20. Strain W303$\Delta$ syr2 lacks the C4-hydroxyl group of the phytosphingosine backbone, strain W303- $\Delta$ elo3 has defective sphingolipids with truncated very long fatty acyl chains, and W303- $\Delta$ syr4 (ipt1) lacks the most complex and abundant yeast sphingolipid, mannosyldiinositolphosphoryl-phytoceramide $\left(\mathrm{MIP}_{2} \mathrm{C}\right)$ (Grilley et al., 1998; Stock et al., 2000). MICs against strains W303- $\Delta$ syr2 and W303- $\Delta$ elo3 were 4-and 2-fold higher, respectively, compared to those for isogenic wild-type strain W303C and strain W303$\Delta$ syr4 (ipt1) (Table 2).

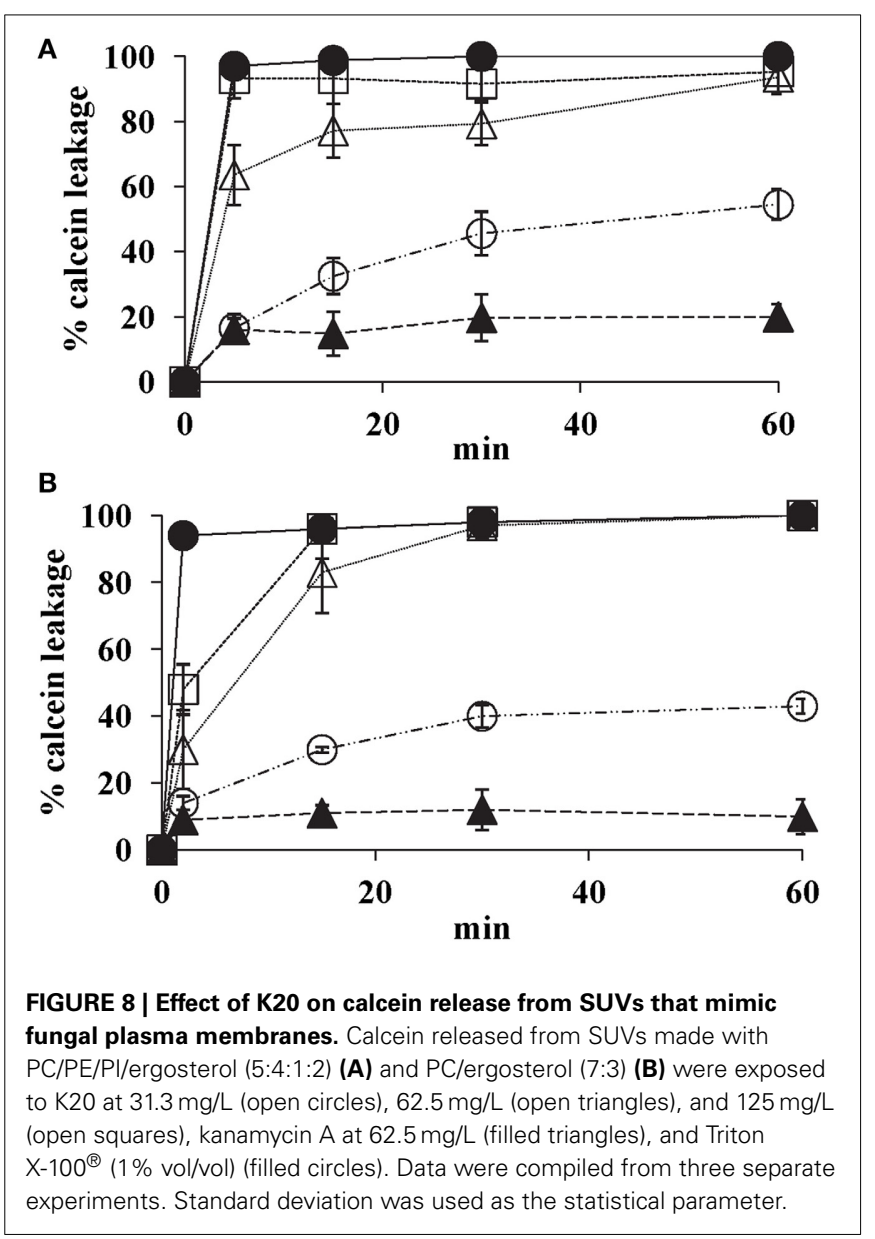

Table 2 | K20 susceptibilities of Saccharomyces cerevisiae sphingolipid biosynthesis mutants ${ }^{\mathrm{a}}$.

\begin{tabular}{|c|c|}
\hline Strain and genotype & MIC $(\mathrm{mg} / \mathrm{L})^{\mathrm{b}}$ \\
\hline W303C (MATo ade2 his3 leu2 trp1 ura3) & 15.6 \\
\hline $\begin{array}{l}\text { W303- } \triangle \text { syr2 (MATo ade2 his3 leu2 trp1 ura3 syr2 } \\
\text { (sur2)::URA3) }\end{array}$ & 62.5 \\
\hline 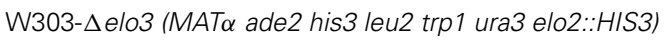 & 31.3 \\
\hline 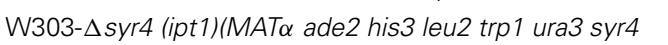 & 15.6 \\
\hline
\end{tabular}

(ipt1)::URA3

a Values are average of three assay determinations.

${ }^{b}$ Microbroth dilution assays were conducted in RPMI 1640 medium.

\section{EFFECT ON PREVENTIVE MURINE LUNG INFECTIVITY OF C. NEOFORMANS H99}

$\mathrm{RAG}^{-/-}$mice treated intratracheally with a mixture of K20 and C. neoformans $\mathrm{H} 99$ cells maintained their body weights over a 15-day infection time course. In contrast, mice treated with C. neoformans $\mathrm{H} 99$ cells only showed weight losses starting at day 10 post-infection (Figure 9). Lung fungal burdens of infected mice were 4 -fold ( $p \leq 0.01$ ) lower with K20 treatment in comparison to untreated infected mice (Figure 10A). Stained images of lung homogenates showed qualitatively decreased fungal burdens 


\section{(10)

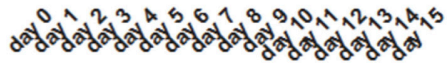

FIGURE 9 | Mean percent body weight change in groups of mice receiving treatments of $\mathbf{K 2 0}$. Treatments with $\mathrm{K} 20$ were one dose/animal of $100 \mu \mathrm{L}$ of $200 \mathrm{mg} / \mathrm{L} \mathrm{K20}$ (filled circles), infected with one dose/animal of $100 \mu \mathrm{L}$ of $C$. neoformans $\mathrm{H} 99\left(5 \times 10^{3}\right.$ cells $\left./ \mathrm{mL}\right)$ mixed with $\mathrm{K} 20(200 \mathrm{mg} / \mathrm{L})$ (open triangles), and infected with 1 dose/animal of $100 \mu \mathrm{L} C$. neoformans H99 $\left(5 \times 10^{3}\right.$ cells $\left./ \mathrm{mL}\right)$ only (filled squares). Data were statistically analyzed and $P$-values determined by One-Way ANOVA methods.

in mice infected with the mixture as compared to mice receiving cells only (Figures 10B,C).

\section{DISCUSSION}

Unlike the difficult and complex synthesis of FG08, the synthesis of K20 is simple and efficient. K20 synthesis involves direct modification of kanamycin A and fewer synthetic steps. Readily available reagents and large stockpiles of kanamycin A (starting material) for its synthesis enhance the prospects for its scalable production (laboratory scale of $\sim 300 \mathrm{~g}$ per batch) and use. For both FG08 and K20, the antibacterial capabilities of the corresponding kanamycin (kanamycin B for FG08 and kanamycin A for K20) are simultaneously diminished with C8 alkyl chain attachment. Thus, a "switch" occurs from bacterial to fungal growth inhibition corresponding to non-alkylated and C8 alkylated kanamycin derivatives, respectively (Table 1). Lacking antibacterial activities, K20 is not expected to promote bacterial resistance with environmental or therapeutic use-a major concern with the use of its parent kanamycin A (Fisher et al., 2012).

Among the fungi species examined, Aspergillus species were least susceptible to inhibition by K20 (Table 1). In contrast, all yeasts tested were growth inhibited by K20 with $C$. neoformans strains showing relatively high degrees of susceptibility. Fusarium species, F. gramineaum and F. oxysporum were also highly susceptible showing that $\mathrm{K} 20$ has broad spectrum antifungal inhibitory capabilities that include filamentous fungi as well as yeast. The generally higher MICs observed with K20 as opposed to the lower MICs for azoles (Table 1) reflect the different modes of action of these antifungal agents. The antifungal MICs observed with K20 are similar to those achieved with recently reported amphiphilic terephalamide-bisurea (Fukushima et al., 2013) and lipopeptides (Makovitzki et al., 2008; Vallon-Eberhard et al., 2008) that are antifungal when they assume high-aspect ratio supramolecular assemblies that interact with target membranes. The comparatively higher antifungal MICs of these amphiphiles and possibly K20 are a consequence of polymeric assembly formation that precedes pore formation in membranes. Consistent with its observed anti-cryptococcal activity, K20 significantly reduced the infectivity of $C$. neoformans $\mathrm{H} 99$ in mice when administered intratracheally together with the pathogen showing that even a single initial treatment of K20 made a significant difference ( $p=0.01$ ) in the propagation of the fungal pathogen. Finally, it is noted that K20 inhibited well-known azole resistant strains C. albicans ATCC 64124, C. albicans B-311, and C. tropicalis 95-41 with MICs that were lower than those of itraconazole and fluconazole (Table 1). Therefore, it appears that K20 is less subject to the azole resistance mechanisms of C. albicans ATCC 64124 and B-311 and C. tropicalis 95-41.

With an octanesulfonyl chain at the $O-6^{\prime \prime}$ position, K20 is an amphiphilic compound which in turn suggests interaction with target cell membranes. Kanamycin A, K20's parent compound has an anti-bacterial mechanism of action that causes protein translation misreading. K20's rapid killing observed in the time-kill curve studies $\left(\sim 10^{3}\right.$-fold CFU decrease in $4 \mathrm{~h}$ at $8 \mathrm{mg} / \mathrm{L}$ ) (Figure 3) suggests direct membrane action as the basis for growth inhibition rather than indirect and slower effects elicited by protein translational misreading or other indirect effects that require cellular processing. Two approaches were used to assess membrane-perturbation effects of K20. Membrane-impermeable FITC uptake studies with cells and calcein leakage studies conducted with model lipid bilayer SUVs suggest that K20's growth inhibitory effect is due to direct and rapid effects on plasma membrane permeability. These membrane perturbing effects resemble those previously observed with K20's predecessor, FG08 (Shrestha et al., 2013). Therefore, the conversion of kanamycin A to K20 not only alters the group of organisms it inhibits but also the mode of action.

Altered K20 susceptibilities of yeast mutants with defective sphingolipids further support interaction with the fungal plasma membrane. Yeast sphingolipids are mainly located in plasma membranes, and they possess fungal-specific structural features that allow high densities of hydrogen and ionic bonding sites for potential interaction with K20 (Stock et al., 2000). S. cerevisiae strain W303- $\Delta$ syr2 which lacks the sphinganine backbone C4 hydroxyl group (Grilley et al., 1998) and strain W303-Aelo3 with truncated fatty acid tails were 4 and 2-fold less sensitive to K20 compared to the isogenic wildtype strain W303C (Table 2). These observations indicate a role for sphinganine $\mathrm{C} 4$ hydroxylated sphingolipids in promoting K20 action on the yeast plasma membrane. Yeast sphingolipids differ structurally from the mammalian sphingolipids and also bacterial membrane lipids (Lester and Dickson, 1993). The former have C4-hydroxylated sphinganine backbones and many have inositolphosphate-containing head groups-features not found in mammalian or bacterial cell lipids These structural differences may account for K20's preferential targeting of yeast and other fungi vs. mammalian and bacterial cells. An absolute requirement for sphingolipids in K20 action, however, is unlikely. SUVs used in this study lacked sphingolipids and were still permeabilized by K20 (Figure 8). It is more likely that combinations of lipids and other membrane components that confer favorable interaction sites (such as, but not exclusively, sphingolipids) are responsible for K20 binding and action. 


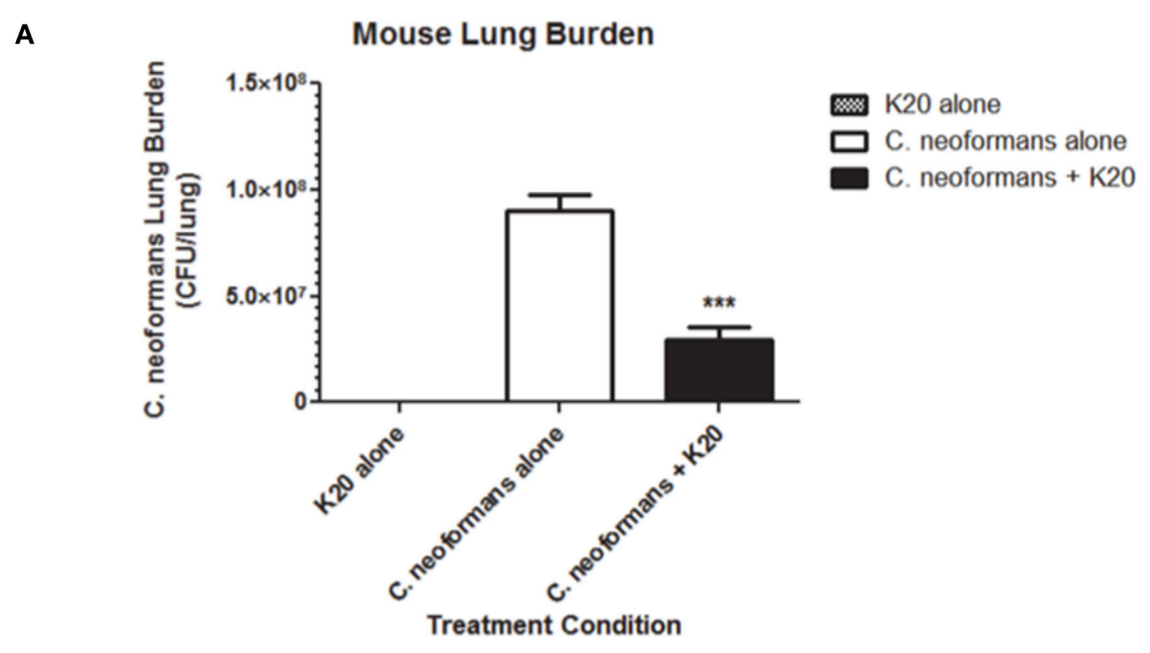

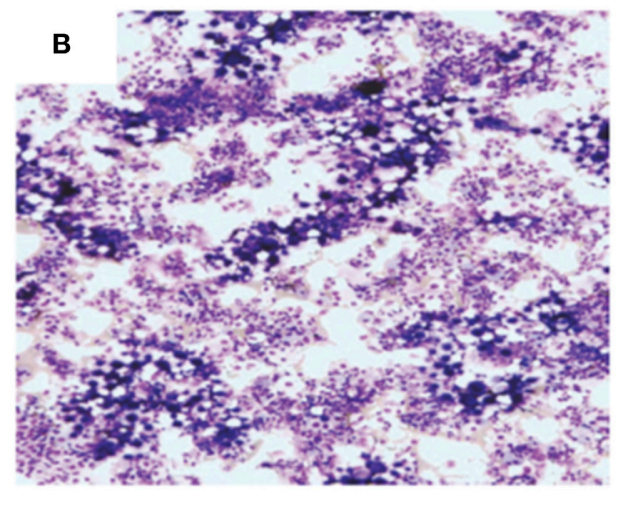

FIGURE 10 | Effect of K20 on C. neoformans $\mathrm{H} 99$ infectivity in a $\mathbf{R A G}^{-/-}$mouse model. (A) Mouse lung fungal burden at day 15 after infection with C. neoformans $\mathrm{H} 99$ cells mixed (black bar) or not mixed (white bar) with K20. Fungal burdens were assessed by plating lung homogenate suspensions for CFU determinations. Control treatment with $\mathrm{K} 20$ and no cells (gray bar) showed no fungal burden.

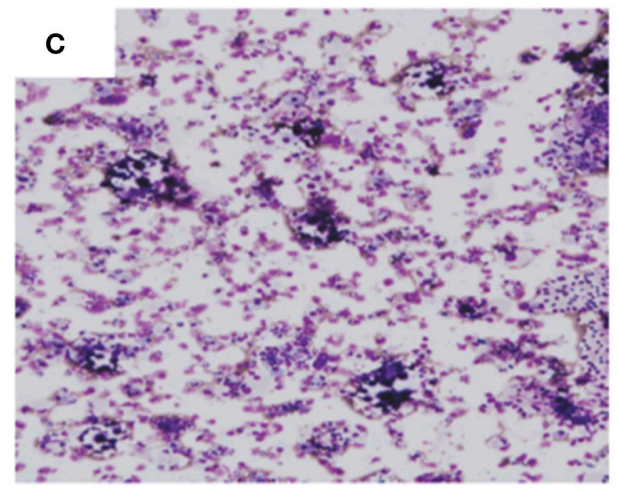

*** Indicates a $p$-value $<0.001$ determined by One-Way ANOVA. Light microscopic images of lung homogenates were prepared from C. neoformans H99 infected mice with no K20 (B) and with K20 (C) exposure. Methanol-fixed homogenates on glass slides were stained with Diff-Quik ${ }^{\mathrm{TM}}$. Yeast cells were visible as large purple colored cells surrounded by an opaque halo.
Similar sphingolipid-promoting, membrane pore forming modes of action may be speculated for antifungal syringomycin $\mathrm{E}$ (Grilley et al., 1998; Stock et al., 2000) and the plant defensin DmAMP1 (Thevissen et al., 2000; Im et al., 2003). In contrast, K20's rapid permeability effect on non-sphingolipid containing SUVs indicates that its mechanism of action differs from that of antifungal plant defensin RsAPF2 (Thevissen et al., 2012). RsAPF2 increases fungal membrane permeability by generating reactive oxygen species following binding to the sphingolipid glucosylceramide (Aerts et al., 2007; Thevissen et al., 2012).

In conclusion, a novel aminoglycoside analog of kanamycin A, K20, with an octanesulfonyl chain as a major structural feature, is a broad-spectrum antifungal that targets fungal plasma membranes. K20 is not hemolytic, showed low mammalian cell toxicities, and it reduced cryptococcal lung infectivity in a mouse model. Because of these features, K20 is suggested as a lead compound for a novel class of therapeutic antifungals as well as crop protectants in agriculture.

\section{ACKNOWLEDGMENTS}

The authors acknowledge financial support from the Utah Science Technology and Research (USTAR) initiative, Baicor LC, and the National Institute of Food and Agriculture, USDA (Utah Agricultural Experiment Station project UTA 1017 to Jon Y. Takemoto). This is approved as UAES publication 8678 .

\section{SUPPLEMENTARY MATERIAL}

The Supplementary Material for this article can be found online at: http://www.frontiersin.org/journal/10.3389/fmicb. 2014.00671/abstract

\section{REFERENCES}

Aerts, A. M., Francois, I. E., Meert, E. M., Li, Q. T., Cammue, B. P., and Thevissen, K. (2007). The antifungal activity of RsAFP2, a plant defensin from raphanus sativus, involves the induction of reactive oxygen species in Candida albicans. J. Mol. Microbiol. Biotechnol. 13, 243-247. doi: 10.1159/0001 04753

Begg, E. J., and Barclay, M. L. (1995). Aminoglycosides 50 years on. Brit. J. Clin. Pharmacol. 39, 597-603. 
Chang, C. W. T., Fosso, M. Y., Kawasaki, Y., Shrestha, S., Bensaci, M. F., Wang, J., et al. (2010). Antibacterial to antifungal conversion of neamine aminoglycosides through alkyl modification. Strategy for reviving old drugs into agrofungicides. J. Antibiot. 63, 667-672. doi: 10.1038/ja.2010.110

Chang, C. W. T., and Takemoto, J. Y. (2012). Aminoglycosides: Synthesis and Use as Antifungals. Appl. No. 13/316,720, US 2012/0316125 Al. Alexandria, VA: U.S. Patent and Trademark Office.

Chang, C. W. T., and Takemoto, J. Y. (2014). Antifungal amphiphilic aminoglycosides. Med. Chem. Comm. 5, 1048-1057. doi: 10.1039/C4MD00078A

Dartois, V., Sanchez-Quesada, J., Cabezas, E., Chi, E., Dubbelde, C., Dunn, C., et al. (2005). Systemic antibacterial activity of novel synthetic cyclic peptides. Antimicrob. Agents Chemother. 49, 3302-3310. doi: 10.1128/AAC.49.8.33023310.2005

Ferket, K. K., Levery, S. B., Park, C., Cammue, B. P., and Thevissen, K. (2003). Isolation and characterization of Neurospora crassa mutants resistant to antifungal plant defensins. Fungal Genet. Biol. 40, 176-185. doi: 10.1016/S10871845(03)00085-9

Fisher, M. C., Henk, D. A., Briggs, C. J., Brownstein, J. S., Madoff, L. C., McCraw, S. L., et al. (2012). Emerging fungal threats to animal, plant and ecosystem health. Nature 484, 186-194. doi: 10.1038/nature10947

Fukushima, K., Liu, S., Wu, H., Engler, A. C., Coady, D. J., Maune, H., et al. (2013). Supramolecular high-aspect ratio assemblies with strong antifungal activity. Nature Comm. 4, 2861. doi: 10.1038/ncomms3861

Grilley, M. M., Stock, S. D., Dickson, R. C., Lester, R. L., and Takemoto, J. Y. (1998). Syringomycin action gene SYR2 is essential for sphingolipid 4hydroxylation in Saccharomyces cerevisiae. J. Biol. Chem. 273, 11062-11068. doi: 10.1074/jbc.273.18.11062

Im, Y. J., Idkowiak-Baldys, J., Thevissen, K., Cammue, B. P. A. and Takemoto, J. Y. (2003). IPT1-independent sphingolipid biosynthesis and yeast inhibition by syringomycin E and plant defensin DmAMP1. FEMS Microbiol. Lett. 223, 199-203. doi: 10.1016/S0378-1097(03)00375-6

Jarvis, J. N., and Harrison, T. S. (2008). Pulmonary cryptococcosis. Semin. Respir. Crit. Care Med. 29, 141-150. doi: 10.1055/s-2008-1063853

Klepser, M. E., Malonel, D., Lewis, R. E., Ernst, E. J., and Pfaller, M. A. (2000) Evaluation of voriconazole pharmacodynamics using time-kill methodology. Antimicrob. Agents Chemother. 40, 1917-1920. doi: 10.1128/AAC.44.7.19171920.2000

Lay, F. T., Brugliera, F., and Anderson, M. A. (2003). Isolation and properties of floral defensins from ornamental tobacco and petunia. Plant Physiol. 131, 1283-1293. doi: 10.1104/pp.102.016626

Lee, H. B., Kim, Y., Kim, J. C., Choi, G. J., Park, S. H., Kim, C. J., et al. (2005). Activity of some aminoglycoside antibiotics against true fungi, Phytophthora and Pythium species. J. Appl. Microbiol. 99, 836-843. doi: 10.1111/j.13652672.2005.02684.x

Lee, J., Park, C., Park, S. C., Woo, E. R., Park, Y., Hahm, K. S., et al. (2009). Cell selectivity membrane phospholipids relationship of the antimicrobial effects shown by pleurocidinenantiomeric peptides. J. Pept. Sci. 15, 601-606. doi: $10.1002 /$ psc. 1157

Lester, R. L., and Dickson, R. C. (1993). Sphingolipids with inositolphosphatecontaining head groups. Adv. Lipid Res. 26, 253-274.

Makovitzki, A., Avrahami, D., and Shai, Y. (2006). Ultrashort antibacterial and antifungal lipopeptides. Proc. Natl. Acad. Sci. U.S.A. 103, 15997-16002. doi: 10.1073/pnas.0606129103

Makovitzki, A., Baram, J., and Shai, Y. (2008). Antimicrobial lipopolypeptides composed of palmitoyl Di- and tricationic peptides: in vitro and in vivo activities, self-assembly to nanostructures, and a plausible mode of action. Biochem. 47, 10630-10636. doi: 10.1021/bi8011675

Mangoni, M. L., Papo, N., Barra, D., Simmaco, M., Bozzi, A., Di Giulio, A., et al. (2004). Effect of the antimicrobial peptide temporin L on cell morphology, membrane permeability and viability of Escherichia coli. Biochem. J. 380, 859-865. doi: 10.1042/BJ20031975

NCCLS. (2002). Reference Method for Broth Dilution Antifungal Susceptibility Testing of Yeasts-Third Edition: Approved Standard M27-A3. Wayne, PA: National Committee for Clinical Laboratory Standards.

NCCLS. (1993). Methods for Dilution Antimicrobial Susceptibility Tests for Bacteria that Grow Aerobically - Third Edition: Approved Standard M7-A3. Villanova, PA: National Committee for Clinical Laboratory Standards.

NCCLS. (2008). Reference Method for Broth Dilution Antifungal Susceptibility Testing of Filamentous Fungi-Second Edition: Approved Standard
M38-A2. Wayne, PA: National Committee for Clinical Laboratory Standards.

Park, B. J., Wannemuehler, K. A., Marston, B. J., Govender, N., Pappas, P. G., and Chiller, T. M. (2009). Estimation of the current global burden of cryptococcal meningitis among persons living with HIV/AIDS. Aids 23, 525-530. doi: 10.1097/QAD.0b013e328322ffac

Sambrook, J., Fritsch, E. F., and Maniatis, T. (1989). Molecular Cloning: a Laboratory Manual. Cold Spring Harbor, NY: Cold Spring Harbor Laboratory Press.

Searles, S., Gauss, K., Wilkison, M., Hoyt, T. R., Dobrinen, E., and Meissner, N. (2013). Modulation of inflammasome-mediated pulmonary immune activation by type I IFNs protects bone marrow homeostasis during systemic responses to pneumocystis lung infection. J. Immunol. 191, 3884-3895. doi: 10.4049/jimmunol.1301344

Segre, A., Bachmann, R. C., Ballio, A., Bossa, F., Grgurina, I., Iacobellis, N. S., et al. (1989). The structure of syringomycin-A1, Syringomycin-E and Syringomycin-G. FEBS Lett. 255, 27-31. doi: 10.1016/0014-5793(89) 81054-3

Shirley, R. M., and Baddley, J. W. (2009). Cryptococcal lung disease. Curr. Opin. Pulm. Med. 15, 254-260. doi: 10.1097/MCP.0b013e3283 29268d

Shrestha, S., Grilley, M., Fosso, M. Y., Chang, C. W., and Takemoto, J. Y. (2013). Membrane lipid-modulated mechanism of action and non-cytotoxicity of novel fungicide aminoglycoside FG08. PLoS ONE 8:e73843. doi: 10.1371/journal.pone. 0073843

Stock, S. D., Hama, H., Radding, J. A., Young, D. A., and Takemoto, J. Y. (2000). Syringomycin E inhibition of Saccharomyces cerevisiae: requirement for biosynthesis of sphingolipids with very-long-chain fatty acids and mannose- and phosphoinositol-containing head groups. Antimicrob. Agents Chemother. 44, 1174-1180. doi: 10.1128/AAC.44.5.1174-1180.2000

Strange, R. N., and Scott, P. R. (2005). Plant disease: a threat to global food security. Ann. Rev. Phytopathol. 43, 83-116. doi: 10.1146/annurev.phyto.43.113004.133839

Sugimoto, Y., Sakoh, H., and Yamada, K. (2004). IPC synthase as a useful target for antifungal drugs. Curr. Drug Targets Infect. Disorders 4, 311-322. doi: $10.2174 / 1568005043340597$

Thevissen, K., Cammue, B. P., Lemaire, K., Winderickx, J., Dickson, R. C., Lester, R. L., et al. (2000). A gene encoding a sphingolipid biosynthesis enzyme determines the sensitivity of Saccharomyces cerevisiae to an antifungal plant defensin from dahlia (Dahlia merckii). Proc. Natl. Acad. Sci. U.S.A. 97, 9531-9536. doi: 10.1073/pnas. 160077797

Thevissen, K., De Mello Tavares, P., Xu, D., Blankenship, J., Vandenbosch, D., Idkowiak-Baldys, J., et al. (2012). The plant defensin RsAFP2 induces cell wall stress, septin mislocalization and accumulation of ceramides in Candida albicans. Mol. Microbiol. 84, 166-180. doi: 10.1111/j.1365-2958.2012. 08017.x

Thevissen, K., Francois, I. E., Takemoto, J. Y., Ferket, K. K., Meertt, E. M., and Cammue, B. P. (2003). DmAMP1, an antifungal plant defensin from dahlia (Dahlia merckii), interacts with sphingolipids from Saccharomyces cerevisiae. FEMS Microbiol. Lett. 226, 169-173. doi: 10.1016/S0378-1097(03) 00590-1

Umezawa, H., Ueda, M., Maeda, K., Yagishita, K., Kondo, S., Okami, Y., et al. (1957). Production and isolation of a new antibiotic: kanamycin. J. Antibiot. 10, 181-188.

Vakulenko, S. B., and Mobashery, S. (2003). Versatility of aminoglycosides and prospects for their future. Clin. Microbiol. Rev. 16, 430-450. doi: 10.1128/CMR.16.3.430-450.2003

Vallon-Eberhard, A., Makovitzki, A., Beauvais, A., Latge, J. P., Jung, S., and Shai, Y. (2008). Efficient clearance of Aspergillus fumigatus in murine lungs by an ultrashort antimicrobial lipopeptide, palmitoyl-lys-ala-DAlalys. Antimicrob. Agents Chemother. 52, 3118-3126. doi: 10.1128/AAC 00526-08

Wilhelm, J. M., Pettit, S. E., and Jessop, J. J. (1978). Aminoglycoside antibiotics and eukaryotic protein synthesis: structure-function relationships in the stimulation of misreading with a wheat embryo system. Biochemistry 17, 1143-1149. doi: 10.1021/bi00600a001

Zhang, L. J., Rozek, A., and Hancock, R. W. W. (2001). Interaction of cationic antimicrobial peptides with model membranes. J. Biol. Chem. 276, 35714-35722. doi: 10.1074/jbc.M104925200 
Conflict of Interest Statement: The authors declare that the research was conducted in the absence of any commercial or financial relationships that could be construed as a potential conflict of interest.

Received: 12 October 2014; accepted: 18 November 2014; published online: 05 December 2014.

Citation: Shrestha SK, Chang C-WT, Meissner N, Oblad J, Shrestha JP, Sorensen KN, Grilley MM and Takemoto JY (2014) Antifungal amphiphilic aminoglycoside K20: bioactivities and mechanism of action. Front. Microbiol. 5:671. doi: 10.3389/fmicb. 2014.00671
This article was submitted to Fungi and Their Interactions, a section of the journal Frontiers in Microbiology.

Copyright (c) 2014 Shrestha, Chang, Meissner, Oblad, Shrestha, Sorensen, Grilley and Takemoto. This is an open-access article distributed under the terms of the Creative Commons Attribution License (CCBY). The use, distribution or reproduction in other forums is permitted, provided the original author(s) or licensor are credited and that the original publication in this journal is cited, in accordance with accepted academic practice. No use, distribution or reproduction is permitted which does not comply with these terms. 